\title{
The Princesse de Monaco, Hubert Robert and the invention of the 'Vieux' château' of Betz
}

\author{
GABRIEL WICK
}

In the increasingly patriotic and nationalistic ideological climate of the I780s, in France, as in Britain and the German states, the focus of practices of picturesque tourism and antiquarianism, initially defined in relation to sites in Italy and the Mediterranean basin, shifted towards the homeland. Travel for pleasure and the visiting of ancient and picturesque sights, once a quintessentially aristocratic rite, became accessible to a far broader public and assumed a more localized character. Infrastructural developments, most notably a safer and more reliable road network, as well as more comfortable carriages also played their part in opening up the countryside to the sort of picturesque outings and experiences that had once only been sought within the confines of the garden. In France in the I78os, gothic novels and plays also engendered a new taste for medieval sights and atmospheres, just as an increasing number of tourist guidebooks and illustrated serial publications vaunted the picturesque character, and historic significance of the French countryside. ${ }^{\mathrm{I}}$ The unparalleled growth of urban centres, and especially Paris, and the demolitions this entailed both to procure building materials and to make space for new developments meant that many ancient buildings were disappearing. Ancient towns and ruins, notable geological features and remarkable natural settings, increasingly came to be seen as destinations for a widely constituted travelling public.

The design and content of aristocratic gardens, which had previously constituted the principal destinations of leisure travel, evolved to meet the changing tastes of this travelling public. In place of the exotic, fantastic and theatrical experiences that had prevailed in some of the most celebrated and innovative aristocratic gardens of the I770s and early I780s, such as the Désert de Retz, Chanteloup, or the Jardin de Monceau, this new culture of domestic tourism and antiquarianism engendered an appreciation of seemingly unmediated, accidental and 'authentic' picturesque experiences. The eclectic and exotic Anglo-chinois taste that had dominated France in the I770s, sought to delight the visitor with a bewildering sequence of scenes and experiences evoking all times and all places. This taste was succeeded in the late I770s and I 780 os by a new genre of landscapes, more grounded in their local context and history, which sought to convey a sense of historical authenticity and draw upon local legends. Paradoxically, this new genre of garden sought to recreate within the confines of the garden the experience of wandering in a wilderness, and present visitors with a sequence of ruins and monuments that would have appeared to have been in place for centuries.

The increasing importance of this broadly constituted visiting public also had an influence upon the sort of objects and experiences presented within much like modern-day museums, garden owners and designers of the I 780 s showed an increasing interest in imbuing their garden compositions with a scholarly rigour and an overall coherence of visitors' experience. Designers of such environments were no longer simply 'composers of landscape', rather they came to act more as curators in the modern sense of that term knowledgeable figures who select and assemble artefacts and contrive a suitable environment for their display and interpretation. 
The phenomenal success of the Marquis de Girardin's garden of Ermenonville, which since the burial of Jean-Jacques Rousseau there in I778, had become the focus of a veritable secular pilgrimage cult, also made aristocratic proprietors keenly aware of the potential value that their gardens held as a medium of self-representation on the public sphere. As the garden of Betz seems to exemplify, in the I780s a number of aristocratic garden owners attempted to capitalize upon the increasing popularity of picturesque tourism to use their gardens to reshape and define their public personas.

Betz is a I2I-acre landscape garden, situated in the Valois region some 38 miles $(6 \mathrm{I} \mathrm{km})$ north-east of Paris (figure I). The park and its château were remade between 1782 and I789 for Marie Catherine de Brignole-Sale, princesse de Monaco (I737-I8I3) and her lover Louis Joseph de BourbonCondé, 8th prince de Condé (I736-I8I8). ${ }^{2}$ Today, few traces of Betz's remarkable eighteenth-century structures or plantings remain (the park survives in private hands but is completely inaccessible to the public). The general form of this garden and its fabriques are relatively well-documented, with three extensive period descriptions. ${ }^{3}$ The garden and these texts have been the subject of extensive research and analysis by the historians Gustave Macon and Maité Bouyssy. In addition, a wealth of primary source material such as Monaco's correspondence and accounts relating to the project also survive. ${ }^{4}$ The appearance of the garden in the eighteenth and nineteenth centuries is also known to us thanks to a number of contemporary engraved views. ${ }^{5}$ Although Betz included a variety of picturesque structures and monuments, which are analysed in the works of Macon and Bouyssy, this article will focus specifically on the Vieux chatteau, the circumstances surrounding its creation and its intended reception.

The park of Betz is bisected by the River Grivette into more or less equal northern and southern sections. The gardens that evolved on the south bank, with its mix of exotic and antique-style structures scattered amidst open meadows punctuated flower beds and clumps of trees, were more in line

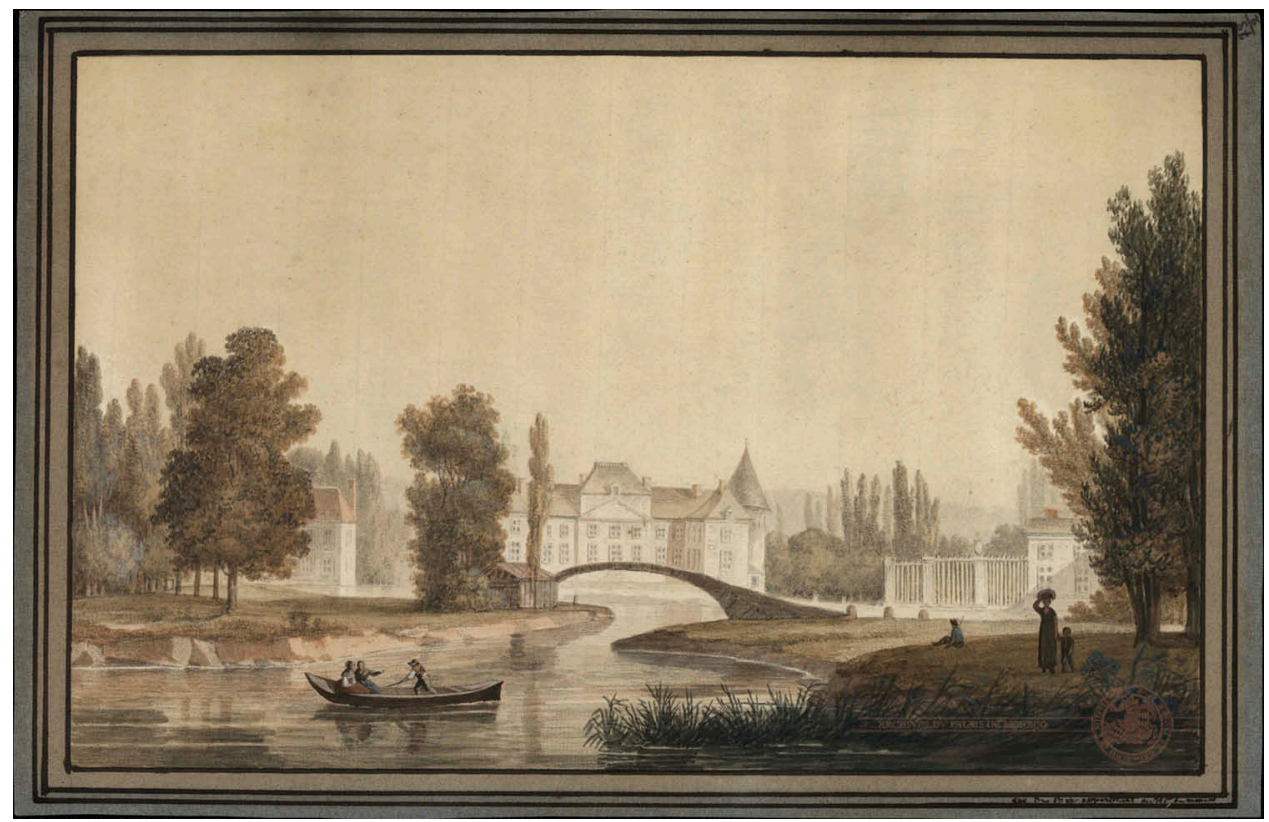

Figure I. View of the Chatteau of Betz, late eighteenth century, watercolour. Archives du Palais princier de Monaco. 
with the Anglo-chinois taste for eclecticism. The structures here were largely derivative of well-known models - there was a floral bridge very similar to the one at Marie-Antoinette's Petit Trianon, a Chinese-style kiosk, which recalled that of Chantilly, and a Temple of Repose, like that of the Désert de Retz. There was a ruin in the form of a Roman bath composed of marble architectural elements salvaged from the sixteenth-century château of Verneuil-sur-Oise which Condé had recently sold for demolition, like the antique baths at Monceau. ${ }^{6}$ There was also a Temple of Friendship, designed by Condé's architect Jean-François Le Roy (I729-I79I), and built to house a cast of the famed sculptural group of the same name by Jean-Baptiste Pigalle $(\mathrm{I} 7 \mathrm{I} 4-\mathrm{I} 785)^{7}$ (figure 2). To informed visitors, the temple would have carried an explicit and very specific symbolism - the original sculpture belonged to Condé and was one of the principal attractions of his Paris residence, the Palais Bourbon. ${ }^{8}$ Monaco was unusually exacting in her attempts to create an authentic atmosphere within this temple and even consulted the noted Hellenist, the Abbé Barthélemy (I759-I8I5), on the furnishings such a structure would have had in antiquity. ${ }^{9}$

Where the mood of the garden on the south bank was cheerfully eclectic and Arcadian, on the Grivette's north bank it took on a decidedly darker tone. Instead of open lawns, this part of the park was covered with existing dense woodlands. The circuit on the north bank began with a small gothic guérite or guardhouse that sat at the limits of the wood at the western edge of the château's great lawn. ${ }^{\text {IO }}$ Penetrating the forest, visitors encountered on either side of the path, emerging from the undergrowth, scattered vestiges of what appeared to have been a vast château. They then encountered the remains of a wall and an immense gateway, surmounted by an inscribed tablet flanked with sculpted figures of two knights in armour (figure 3). The inscription above this doorway recounted that the château had been built by a certain Roger de Betz in II82, and then passed to the brothers Girard and Thibault de Nanteuil in I257, and that it was subsequently given to a religious order on Thibault de Nanteuil's departure for the Crusades.

Further on, visitors encountered a monumental stair that led up to what appeared to be a semi-ruinous elevated walkway of rough planks supported by stone piers and arches (figures 4 and 5). At the end of this 90-ft-long walk, visitors discovered a tower some $\mathrm{I} 4 \mathrm{ft}$ in diameter and $\mathrm{I} 32 \mathrm{ft}$ in height. Just as

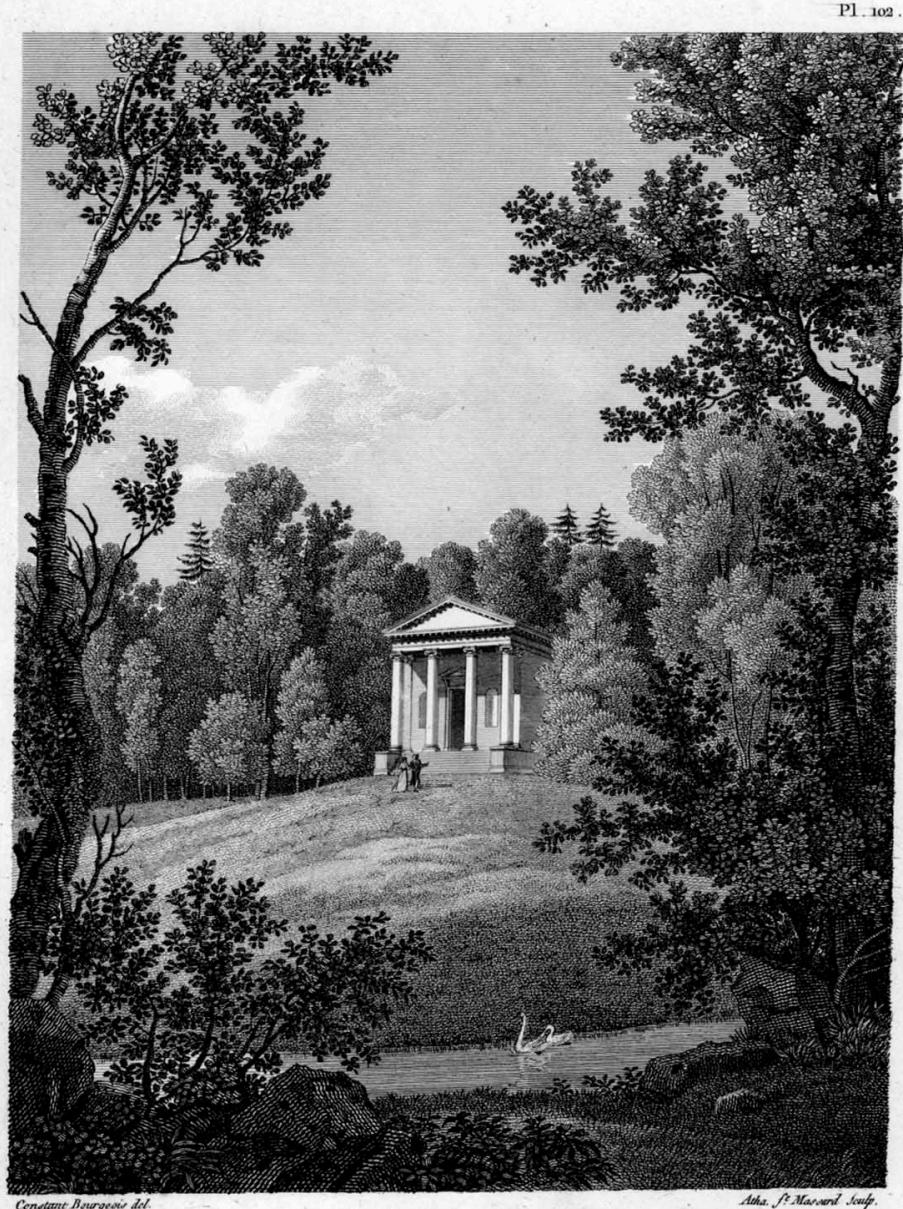

Le TEMPLE de 1'AMTTIE dans le Pare de BETZ

The TEMPLEE of FRIENDSHIP in the Park of BETZ. 【 Der TEMPEL der PREUNDSCHAFT im Park auBETZ

figure 2. Constant Bourgeois (1767-1841) (draughtsman) Anna Athenas Massard (engraver), The Temple of Friendship in the Park of Betz, from Alexandre de Laborde, Description des nouveaux jardins de la France et de ses anciens châteaux (Paris: impr. de Delance, 1808). Author's collection. 


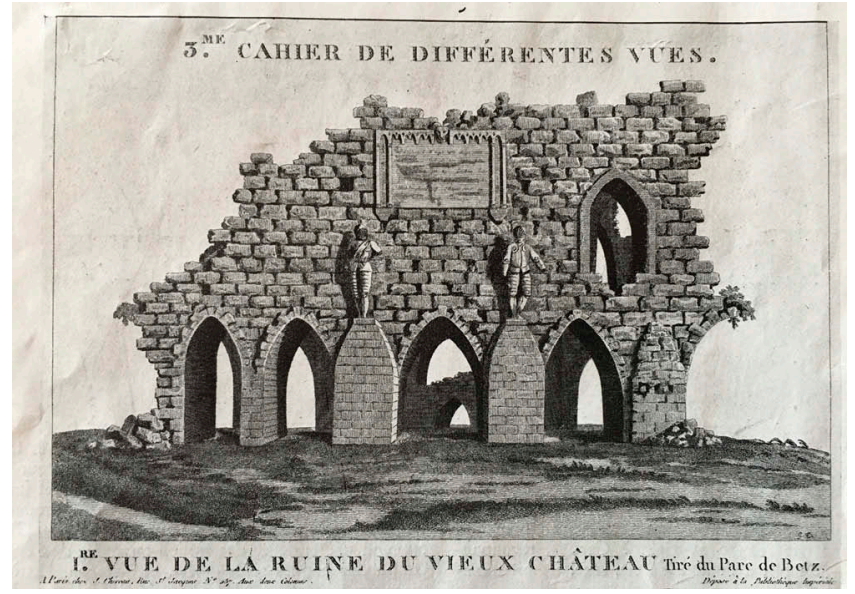

FiguRE 3. Jacques-François Chéreau (1742-1794), ière vue de La Ruine du Vieux château tiré du parc de Betz, from zème Cahier de differentes vues (Paris: J. Chereau, s.d.). Private Collection.

the walkway had been patched with wooden boards, so too the tower sported a dramatic gaping breach in its uppermost section. Bertrand Barère, who left an account of his visit in $\mathbf{1 7} 88$, and appears to have been unaware that the tower was a pastiche, wrote that the fissure filled those who dared approach with apprehension. ${ }^{\text {II }}$ The tower's apparent instability contributed to the visitors' impression that their discovery of the ruins was accidental and that they were in effect trespassing in a place that was not intended to be visited - a sensation that only added to the structure's air of historical authenticity.

Inside the tower, visitors found a salon in the gothic style illuminated by four large stained glass windows with the heraldic devices of Thibault de Nanteuil, which were also to be found in marble inlays in the floor. Its walls were decorated with citations taken from the work of the historian and medieval lexicographer Jean-Baptiste de La Curne de Sainte-Palaye (I697-I78I). A pastiche statue of Thibault de Nanteuil's wife, Adèle de Crépy, presided over an equally modern gothic-style chimney piece. But the salon also housed an authentic work of art, a sixteenth-century bas-relief depicting a battle scene attributed to the sculptor Jean Goujon (c. I5IOI 565). ${ }^{12}$ Macon's manuscript guide informs the visitor that this artwork had been salvaged from Condé's château of Laversine, which the prince had sold

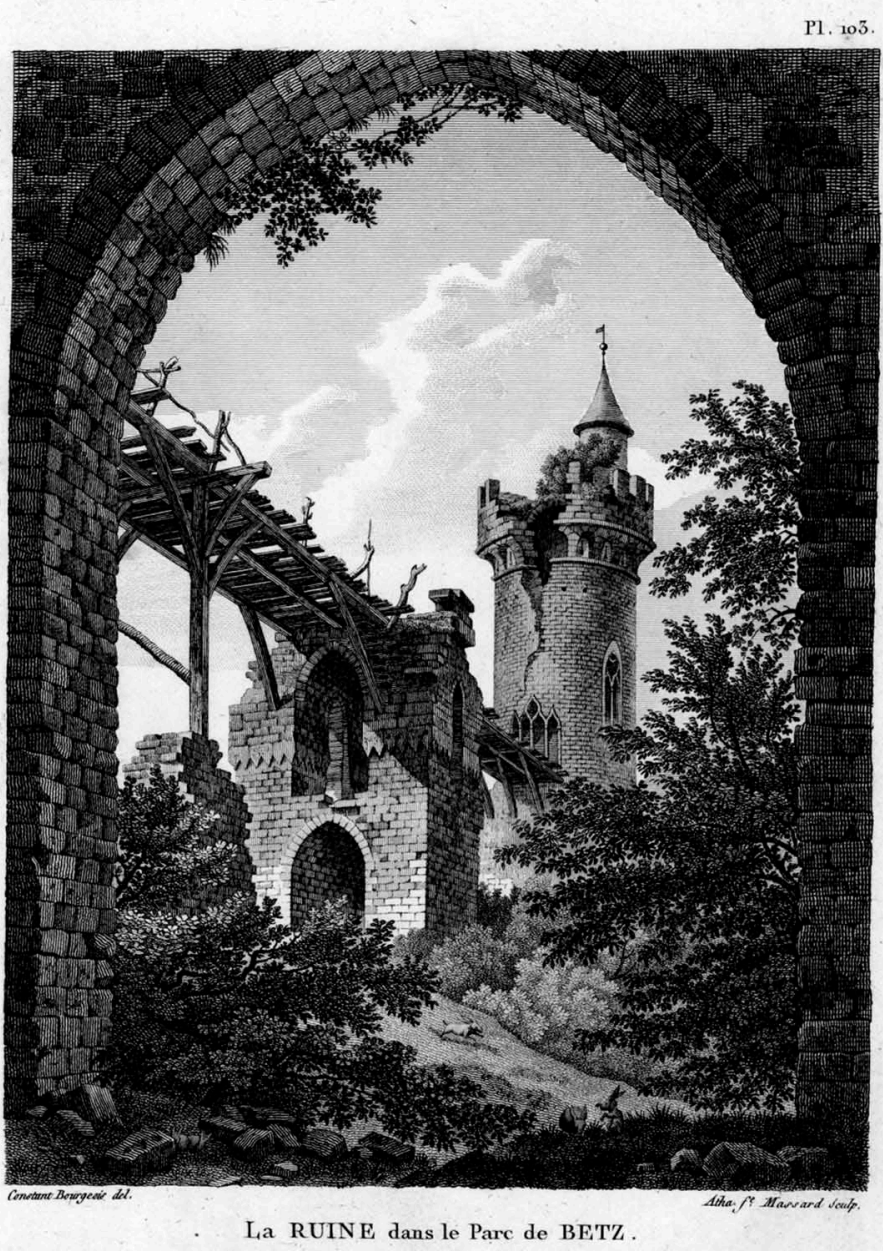

The RUIN in the Park of BETz. 【 Der RUIN im Park zu BETZ.

FIgURE 4. Constant Boureois, The Ruin in the Park of Betz, from Alexandre de Laborde, Description des nouveaux jardins de la France et de ses anciens châteaux (Paris: impr. de Delance, 1808). Author's collection.

for demolition in May I782. Macon notes that a clause in the act of sale with the entrepreneur Jacques Berthault stipulated that certain sculptural elements be salvaged for the prince. ${ }^{13}$ As we have already seen with the 'Roman' baths 


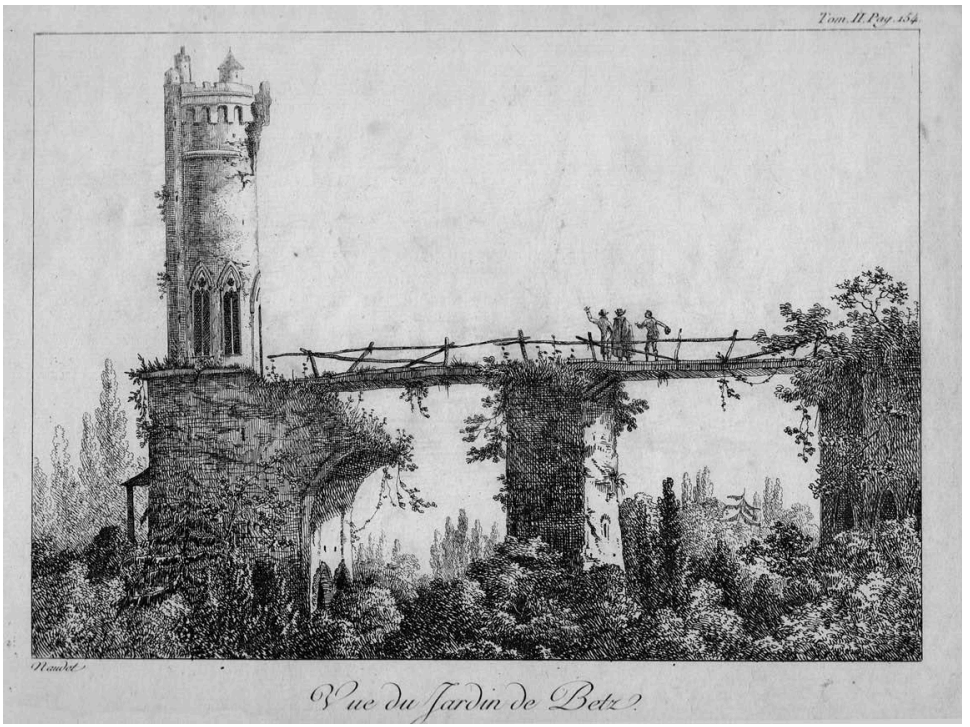

Figure 5. Théodore-Charles Naudet (1773-1810), Vue du jardin de Betz, engraving, from Jacques Cambry, Description du départment de l'Oise (Paris, Didot,1803), T.II, p.14. Author's collection.

on the garden's south bank, the reuse of historic architectural elements constituted something of a consistent thread that ran throughout the garden of Betz.

Moving from the salon out to the terrace the surrounded it, from here visitors could ascend via a seemingly precarious stair leading to a crenelated platform above. Like the walkway, the stairs were fashioned to appear as if they had been repaired in a makeshift manner with rough timber so as to heighten the sense of peril as visitors ascended. From the summit of the ruin, they could survey a landscape rich in authentic medieval ruins that included the very distant Abbey of Saint-Christophe (on a hilltop in the great forest of Halatte), as well as the villages of Nanteuil-le-Haudouin and Crépy-en-Valois (names that had evidently inspired those of the fictional lovers Thibault de Nanteuil and Adèle de Crépy). ${ }^{\mathrm{I}}$ Both the view of distant ruins and the interweaving of names drawn from the locality further contributed to the garden's air of historical veracity.

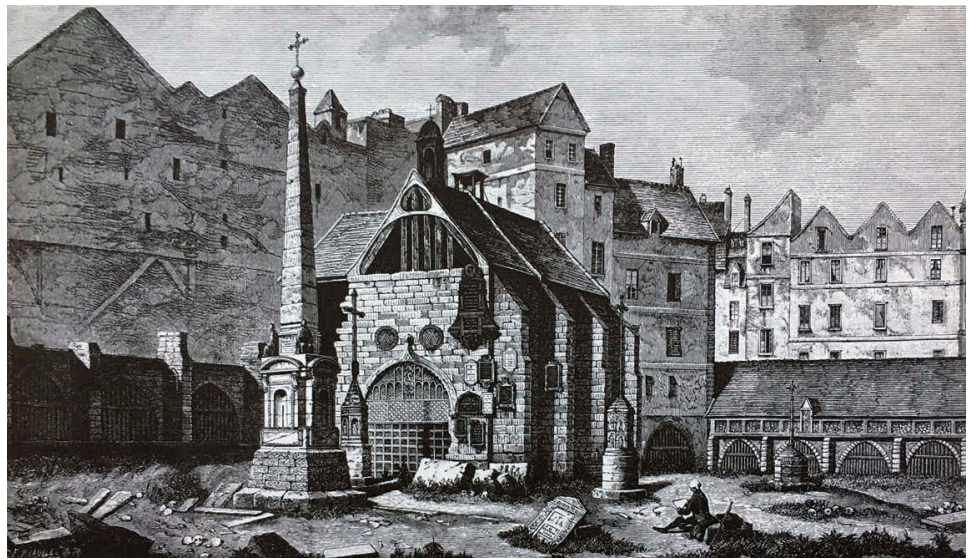

Figure 6. 'View of part of the Cimetiére des Saints innocents, vue le 15 février 1786' from Fedor Hoffbauer, Paris á travers les ages, 2 vols. (Paris: Firmin-Didot, 1875-1882), Vol. 1, p. 365. Private collection.

Descending from the tower, visitors found themselves in a dense wood whose plantings of Scots pines created a sombre atmosphere. A clearing demarcated by Lombardy poplars contained a column with a Latin inscription informing visitors that this place had been made sacred by long years of mourning and that the 'profane' should go elsewhere. ${ }^{15}$ Visitors then encountered a series of tombs. The first was an obelisk identified by its inscription as the tomb of Nicolas Hennequin of Paris (died I 556) and his wife, Jeanne Le Gras (died I 532). The monument, salvaged from the burial ground of Les Innocents at its demolition in I786, was also attributed to Goujon ${ }^{16}$ (figures 6 and 7 ).

It seems likely that the very public effort led by the architectural theorist Antoine Quatremère de Quincy (I755-I849) to pressure the authorities to save Goujon's bas-reliefs from the Fountain of the Holy Innocents when the burial ground was closed, played a part in motivating the princesse to seek out her own monument for Betz. ${ }^{17}$ Just as the monuments at Betz integrated both historical and modern elements, so too Goujon's bas-reliefs from the fountain at Les Innocents were incorporated into a new freestanding monument that included elements by the sculptor Augustin Pajou (I730-I809). ${ }^{18}$ Les Innocents was very much a banner project that symbolized the crown's broader 


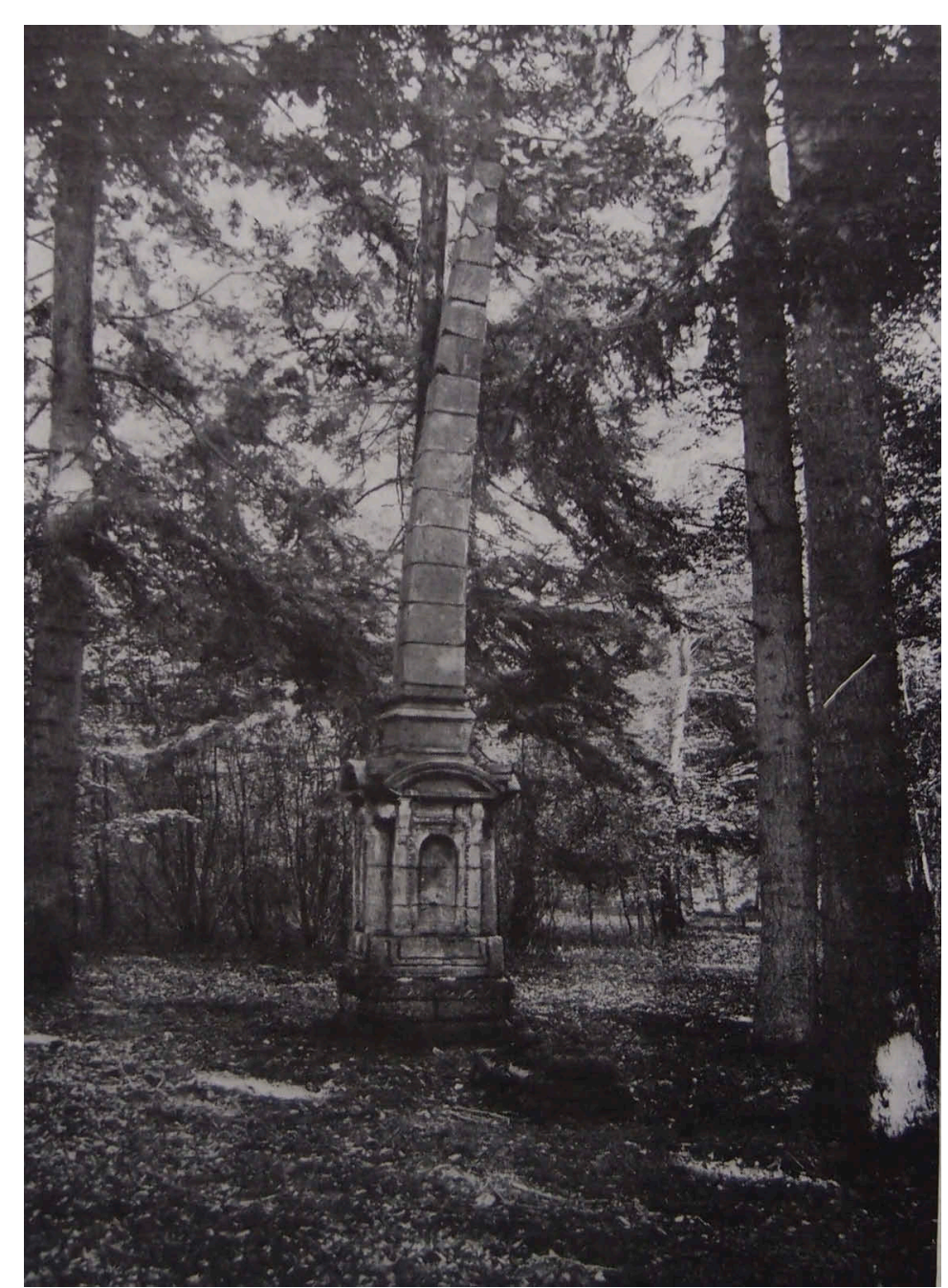

FIGU RE 7. The monument of Nicolas Hennequin and Jeanne le Gras in its location in 1907 at Betz. Reproduced from Alber Maumené, 'Les "Fabriques" du parc de Betz', La Vie á la Campagne, $N^{\circ} 75$ (1909), pp. 265-270. My thanks to Bertrand Gautier of Talabardon E Gautier for having provided me with this document.

ambitions for the regeneration of the capital's densely crowded core - so for the princesse the undertaking of a similar adaptive reuse of salvaged artefacts within her garden became a means of demonstrating her progressiveness and modernity.

Moving further into the grove, visitors encountered an elaborately carved Roman sarcophagus upon which a Latin inscription recorded the name of the eques who had formerly been interred within. On the opposite side, what appeared to be a later inscription in Gothic lettering recorded that the sarcophagus had been reused by Adèle de Crépy to inter the remains of her beloved Thibault after his death in the Holy Land. ${ }^{\text {I9 }}$ Macon's manuscript guide informs the visitor that this tomb was the work of the contemporary sculptor Mézières who had worked at the Palais Bourbon and Chantilly. ${ }^{20} \mathrm{~A}$ short distance beyond the tomb of Thibault, visitors discovered that of Crépy herself, lit, we are told by a solitary lantern. ${ }^{2 \text { I }}$ This was a sarcophagus supported by four chimeras (her device) and surmounted by an elaborate effigy. An inscription recorded that she had died of grief after her long wait for the return of her husband. Macon's manuscript guide also describes this monument as a pastiche by Mézières that incorporated authentic sixteenth-century sculpted elements by Goujon. ${ }^{22}$

While 'tomb valleys' played something of a stock role in Anglo-chinois gardens of the I770s such as that of the duc de Chartres at Monceau, such compositions sought to elicit a generalized sense of melancholy on the part of the visitor. At Betz, however, the monuments and their inscriptions served to enrich and lend detail to an overarching narrative of the garden. The intermingling of historically significant monuments alongside pastiche ones added a layer of verisimilitude to the narrative and challenged visitors to discern between the authentic and the contrived elements.

Moving westward, visitors then encountered a semi-ruinous gothic chapel decorated with Adèle's device, the chimera, and an inscription recording that she was its founder and benefactor. Macon's guide attributed these ornaments to Condé's artist Landragin. ${ }^{23}$ The chapel's facade was dominated by an historically significant artwork - a statue of the Virgin and child that Macon notes had probably been salvaged from the medieval Abbey of Sainte-Victoire de Senlis which was closed and subsequently demolished in $1783^{24}$ (figure 8 ).

Nearby, in the midst of a mossy rocky clearing, surrounded by a simple vegetable garden, was a hermitage built upon a grotto (figure 9). Here the princesse offered her visitors something of a more interactive experience, as she had in fact hired a hermit to inhabit the place and to show it to 
THE 'VIEUX CHÂTEAU' OF BETZ

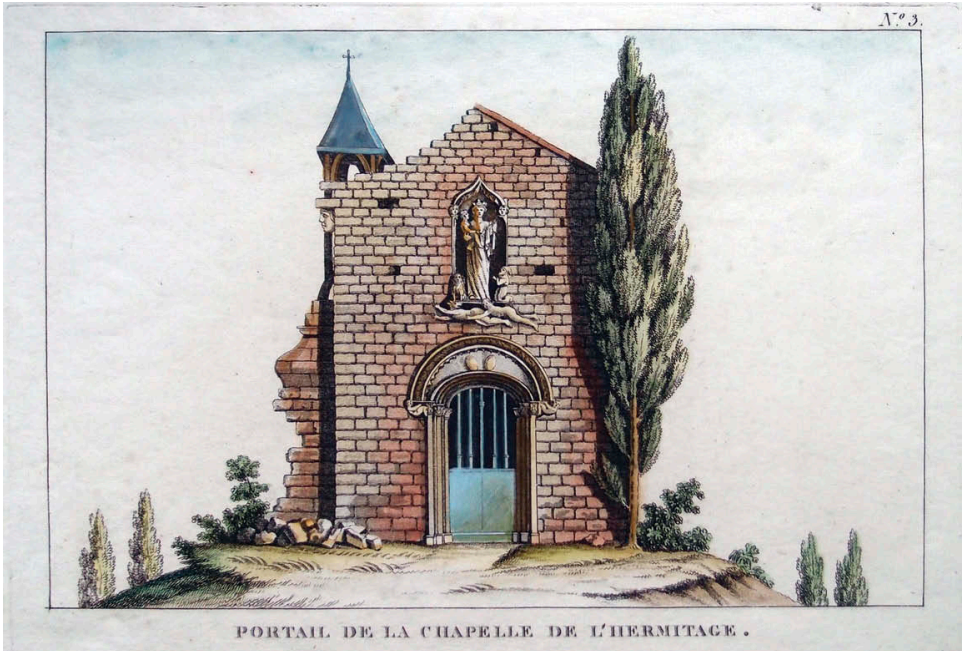

FIguRE 8. Jacques-François Chéreau (1742-1794), Portail de la Chapelle de l'hermitage de Betz, from Cahier de differentes vues (Paris: J. Chereau, s.d.). Author's Collection.

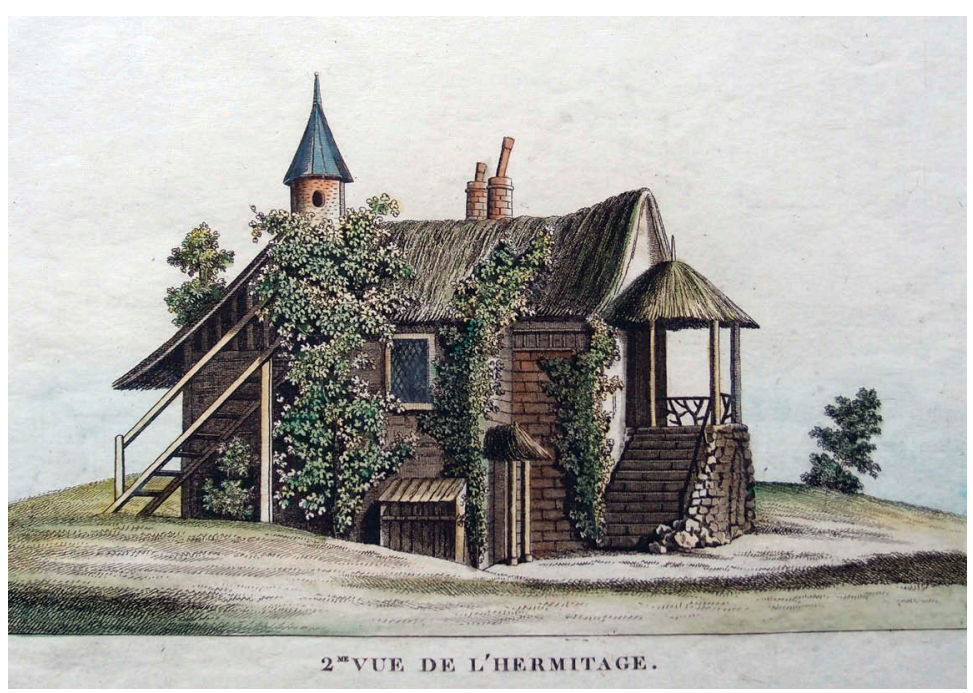

FIgURE 9. Jacques-François Chéreau (1742-1794), Vue de l'hermitage de Betz, from Cahier de differentes vues (Paris: J. Chereau, s.d.). Author's Collection. visitors. ${ }^{25}$ Within the hermitage, visitors discovered an oratory whose walls and rough furnishings were upholstered with mosses and matting of woven-rush. It contained a small library of devotional texts and was decorated with a number of statues of coenobites. The grotto below housed a collection of shells, minerals and plant specimens that was perhaps intended to evoke in rustic terms Condé's natural history cabinet at Chantilly, considered one of the finest in the kingdom. ${ }^{26}$ Beyond the hermitage, a primitive bridge, supposedly built by the hermit, surmounted by a cross, symbolized, according to Macon's manuscript, the unity of all Christians. The chapel, the hermitage and the bridge served to emphasize the princesse's piety and charity, but also constituted a direct narrative link between Adèle de Crépy and Monaco because it was the princesse's hermit who was supposed to have restored the medieval chapel after it had fallen into ruins. ${ }^{27}$ Much as we have already seen with the tombs, the metanarrative of rebuilding and restoration evoked by the chapel served to represent Monaco's Betz as a good and pious undertaking.

Visitors would have then crossed over a bridge to the south bank of the Grivette with its more cheerful mixture of classical temples and exotic pavilions. Having passed through the valley of ruins and tombs, supported by their faith, they received their just reward - an Arcadian Elysium of open lawns, flowers.

The most direct source of inspiration for the Vieux chatteau and the valley of tombs may have been Monaco and Condés shared love for theatre. In particular, a comic opera with a chivalric theme, Matroco, had been written on their behalf by the playwright Pierre Laujon (I727-I8I I) and the composer André-Ernest-Modeste Grétry (I74I-I8I3). The piece was first performed at Chantilly in November 1777 and reprised at the théatre de l'Hôtel de Bourgogne in February $1778 . .^{28}$ In Laujon's words, Matroco was a travesty of chivalric tales and poetry that included elaborate ceremonies, magical sacrifices, transformations, enchantments, rescues by knights, combats with dwarves and giants, and the attack and breaching of castles. Thus, the Vieux château may have served to render this theatrical triumph and its ephemeral decors in an enduring form in the garden.

Another source of inspiration for the couple may have been the ruined château de Bourbon-l'Archambault, the cradle of the Bourbon dynasty since the tenth century, which had been in the possession of the Bourbon-Condé since the I660s (figure Io). Condé knew this structure well because he stayed 


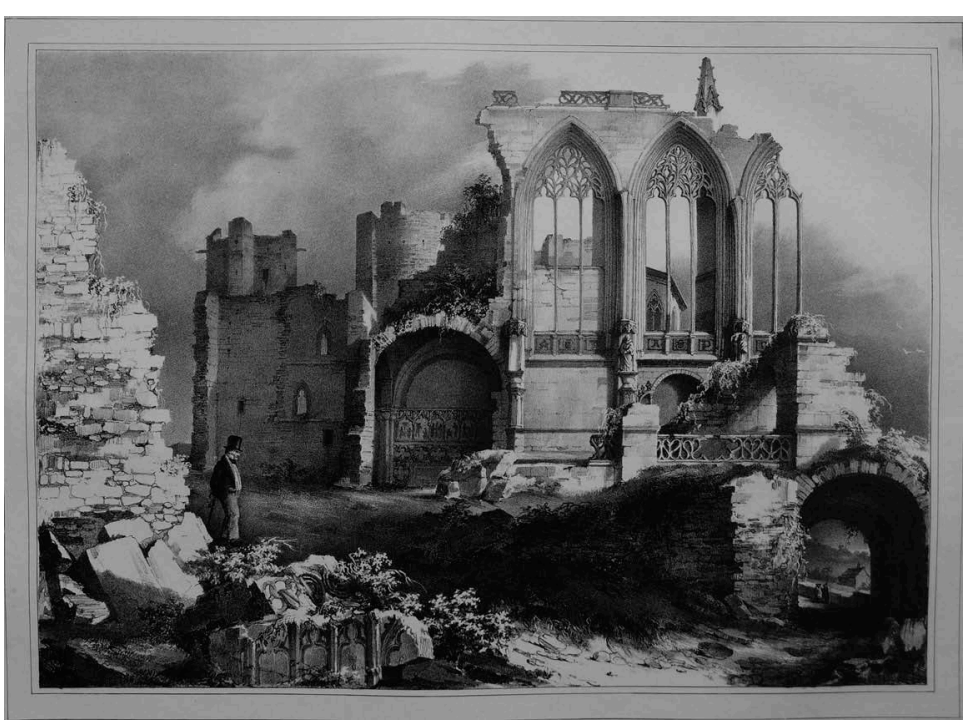

Figure io. Durand \& Tudot, St. Chapelle en Ruines au château de Bourbon l'Archambault, 1836, lithograph, $31 \times 44 \mathrm{~cm}$, Author's Collection.

there frequently to take the waters from its thermal springs as a cure for crippling attacks of gout. An undated letter from Condé to Monaco written at Bourbon describes the ruins of the 'Vieux château' there in terms that are very similar to the ruins they would erect at Betz. ${ }^{29}$ Condé was especially moved by the brilliant colour of its stained glass, the 'inscribed names and sculpted figures of the most ancient Bourbons', and the 'antique majesty of the place'. He also took pleasure in describing the picturesque nature of its site, and the character of the different vantage points and approaches.

In addition to the two period descriptions mentioned in the introduction (see above), a pair of texts that were almost certainly produced at the behest of Monaco and Condé as guides to the garden provide remarkable insight into how the couple intended it to be received by the general public. The first is a five-page manuscript description, titled 'Notes on the old château of Betz', that was given to visitors on arrival and is today preserved amongst the papers confiscated from the princesse by Revolutionary authorities after her emigration in $1789.3^{\circ}$ The document's anonymous author begins by evoking and then refuting the supposed assertions of some antiquarians that the ruins might be those of the favourite villa of the Merovingian king Clotaire I (498-56I), described by the chronicler Grégoire of Tours (c. $53^{8-594)}$, and thought to be located in the neighbouring village of Bargny (which the author notes is visible from the salon of the Vieux chateau). Instead, the author concludes that the ruins are far more likely to be associated with the thirteenth-century comte de Nanteuil, whose heraldic devices are to be found on one of the surviving walls at the entrance to the site. What then follows is a dry discursive history of the ruins that situates them in the broader history of France. ${ }^{3 \mathrm{I}}$ The text is remarkable for its scholarly tone and its flawless imitation of style of contemporary antiquarian scholarship.

The second is a verse description of Betz written in 1785 by the poet Joseph-Antoine-Joachim Cerutti (I738-I792). Cerutti was an intimate of the princesse and actively involved in the creation of Betz - he composed the inscriptions that graced the Temple of friendship on the south bank of the Grivette. Cerutti's model for such a guide in verse was doubtless the poem Les Jardins, ou l'art d'embellir les paysages (Paris: impr. de F.-A. Didot l'aîné, I782) by the Abbé Jacques Delille (I738-18I3), one of the most popular publications of the period. His verse guide provides a far more truthful discussion of the contrived nature of the ruins. It is significant that Cerutti's text celebrates both the skill of the garden theorist François-Henri d'Harcourt, comte de Lillebonne and later duc d'Harcourt (I726-1802), who gave the garden its general form, and more specifically Hubert Robert for designing and putting the finishing touches on the Vieux château:

This Raphäl of landscapes,

The poet of time, Robert sketched

This picturesque castle, born a ruin.

The artist mutilated his works as he created them.

For them, long centuries were but short instances.

Each blow of the hammer imprinted them with a century.

To console them, to flatter their precocious old age,

He gave them the pride of an ancient nobility. ${ }^{32}$

It is remarkable that although both texts were almost certainly produced at the behest of Condé and Monaco, they would seem to have two such entirely contradictory intentions. The historical description of the Vieux château goes to great lengths to establish an air of historical credibility around the ruins while Cerutti's poem acknowledges and even vaunts their artificiality. Rather than 
contradicting one another, the two texts might have been intended to frame the ensemble of pastiche structures as something of an historical riddle - an elaborately contrived enigma that the visitor would unravel slowly over the course of a promenade. They show that while Monaco and Condé were determined to go to extraordinary lengths to create an entirely credible historic experience for their visitors, it also seems that they wished them to be fully aware of the subtle artistry, erudition (and expense) that had been mobilized for their enjoyment. The couple desired that visitors should to be deeply affected by the tragic fates of Thibault and Adèle; however, they also needed visitors to be at least partially conscious of the fact that this was a work of fiction. The contradiction points to an interesting paradox in the creation of an historic pastiche. If the illusion was too flawless and too impenetrable, it risked being received simply as an historical artefact. In order for the narrative of Thibault and Adèle to cast the relationship of Monaco and Condé in a positive light, the couple needed at some point to reveal their own roles in its creation.

Monaco and Condé had an active interest in using the garden to court the public's sympathy because the irregular nature of their relationship meant that they were forbidden from participating in court life and more traditional forms of aristocratic representation. Monaco's own story was the very stuff of romance. In December I770, the court of peers of the Parlement de Paris had granted her a séparation de corps et de biens from her abusive and erratic husband, Honoré III Grimaldi (I720-I795), sovereign prince of Monaco. At that point, for some 5 years already, the princesse had been in a purportedly Platonic affair with Condé. As second-ranking prince of the blood, Governor of Burgundy and Grand-Maitre of the king's household, Condé played a central role in the functioning and ceremonial life of the monarchy. He was also a celebrated war hero - a rare distinction for a member of the Bourbon dynasty in this period. Perhaps because of Condé's prominence, and also because his mistress' husband was a sovereign prince, Louis XV forbade Monaco from appearing at court, letting it be known that she, like any noblewoman who refused to live with her husband, should retreat to a convent. Little changed with the accession of Louis XVI and Marie-Antoinette in I774: they too took the position that for the moral well-being of the kingdom, the princesse should withdraw from public life. ${ }^{33}$ In this context, the Betz project and its romantic narrative assumes a wholly more political significance. Although the princesse reigned as the acknowledged hostess over both of the prince's official residences, the Palais
Bourbon in Paris and Chantilly, the fact that she did so was in direct contradiction of an express command of her monarch.

In light of this formal interdiction on the couple's living together or participating jointly in court life, their remarkable architectural and artistic patronage takes on a distinctly propagandistic and symbolic character. Even before the princesse's separation, it seems that Condé began to create garden structures at Chantilly that would give a certain material expression to their mutual devotion. Just after they met he constructed an immensely expensive Temple de Venus which sat on the Île d'Amour. Between 1770 and I775, he and his architect JeanFrançois Le Roy (I729-I79I) built an elaborate series of structures at Chantilly - a Chinese-style kiosk, an innovative 'Jardin Anglois' supposedly designed by Condé himself, and an ersatz hamlet of cottages whose rustic exteriors hid luxurious interiors. These innovative additions to one of the kingdom's most celebrated estates ensured that the couple's peers as well as the broader public would continue to visit Chantilly despite the royal sanction on the estate's master and mistress. In Paris, the princesse de Monaco was engaged in similarly prominent works: between I 770 and I774, the architect Alexandre-Théodore Brongniart (I739-I8I3) built her the hôtel de Monaco, one of the capital's most luxurious and architecturally innovative houses. ${ }^{34}$ The proximity of Monaco's hôtel to the Palais Bourbon, underscored the couple's bond, while its unrivalled elegance and modernity manifested her independence and wealth. Such symbolic evocations and even celebrations of the couple's intimacy were already gestures of disobedience that kept the couple in the public eye.

Betz, which the princesse acquired in $\mathrm{I} 780$, was ideally suited to expressing the couple's bond and attracting attention and visitors. As Monaco's neighbour the Baron Frénilly noted, Betz was neither too close nor too far from Condé's Chantilly (24 miles away). ${ }^{35}$ It sat only a few miles from the Route Royale taken by the court on its annual voyage to Compiègne. It was also only I I miles from another important pole of aristocratic life, the historic château of the Orléans family, Villers-Cotterets, as well as a number of other important dynastic seats. Furthermore, it was situated in a region that was particularly popular for picturesque tourism. The counties of Valois and Senlis constituted something of a heartland for the kingdom of France in the medieval and Renaissance periods and were rich in monuments and ruins - nearby was Pierrefonds, one of the most important medieval ruins in France, as was the picturesque Abbey of Chaalis. The neighbouring villages of Nanteuil-le-Haudouin and Crépy-en-Valois were both notable for their medieval 


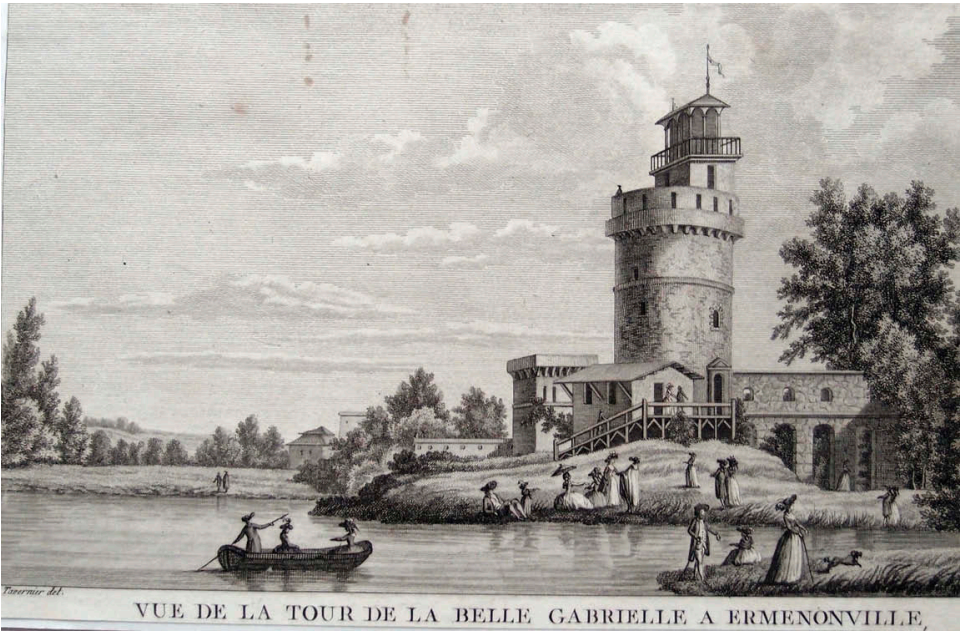

Figure I I. François Denis Nee (engraver) Tavernier de Jonquiere (draughtsman), La tour de la Belle Gabrielle et le désert d'Ermonville. Private Collection.

architecture. ${ }^{36}$ Most importantly, however, Betz lay only $\mathrm{I} 2$ miles from Ermenonville, the garden of René-Louis, marquis de Girardin (I735-I808), which since 1778 was the resting place of Rousseau. In light of the region's rich history in the late I770s, Girardin added a pastiche medieval tower to Ermenonville called La Tour de la Belle Gabrielle (figures II and I2). He pretended it had been the trysting place of King Henri IV (I553-I6IO) and Gabrielle d'Estrées (I573-I 599). This structure was doubtless an important source of inspiration for the structures that would subsequently arise at Betz. ${ }^{37}$ It seems that Monaco aspired to attract a public that went well beyond the exclusive circle of her intimates and peers because, as Maité Bouyssy notes, she erected a 'Hôtel des Amateurs' to accommodate visitors at the entrance..$^{38}$

The princesse quickly set about transforming the château of Betz with the architect Jean-Benoit-Vincent Barré (I730-I824). ${ }^{39}$ It was to be a modern and comfortable residence in an understated neoclassical style. As soon as the château was finished in $\mathrm{I} 782$, Monaco turned her attentions to the gardens. The project at Betz offered the princess the opportunity to be implicated in the design and execution of a work of architecture in a much more personal and direct manner. She personally supervised its development and administration and paid for the works with a monthly allocation (generally of 500 livres per month) from her private purse. ${ }^{40}$ These outlays continued in a regular fashion from I 782 until I 788 when they began to take on a dramatic new scope - in May I 788 alone she dispensed some $\mathrm{I} 7400$ livres on Betz, which was followed in June by payments totalling some 25 ooo livres (it seems likely that these related to the construction of the Vieux château itself)..$^{41}$ Condé was also heavily involved in the project. The garden historian Ernst de Ganay observes that it was Condé who had recommended to the princesse that Harcourt be invited to supervise the design of the garden..$^{42}$ A letter from him to Monaco in September I 788 described how he yearned to become once more the simple 'bourgeois de Betz', commanding only M. Le Court, the estate architect and Herbin, its hermit. ${ }^{43}$

Documents from the princesse's household accounts shed more light on the host of figures who managed and executed the project. ${ }^{44}$ The works were overseen by the princesse's household architect Le Court and her Paris gardener, Herisson (about whom very little else is known). The involvement of a number of people who worked for Condé at the Palais Bourbon and Chantilly such as the architect Le Roy, and the sculptors Jean-Baptiste Stouf, JeanBaptiste Landragin and a certain Mézières, also served to further emphasize the ties between Monaco and the prince. ${ }^{45}$ It also seems highly likely that the architect Brongniart, who had already been employed on the princesse's townhouse and who continued to work regularly in her service, was most likely responsible in the design of the Vieux chateau and the gothic structures nearby. In $\mathrm{I} 778$, he had designed a gothic oratory for the garden of the Hôtel de Monaco that stylistically prefigures the tower and hermitage at Betz. ${ }^{46} \mathrm{~A}$ receipt from April I788 in the Monaco Palace Archives records that he was paid an honorarium (for an unspecified sum) that coincides with the most important and costly phase of the development of Betz in $1788 .{ }^{47}$ The Vieux chatteau also strongly resembles some of the designs for gothic structures in the collection of Brongniart drawings at the Louvre. ${ }^{48}$

In Cerutti's description, however, all of these figures are eclipsed by Harcourt and Hubert Robert. The involvement of two such prominent figures conferred an essential prestige and fame upon Betz and ensured that fashionable public would wish to visit. Harcourt had gained an important reputation as a theorist of landscape design by circulating amongst his acquaintances a manuscript giving advice on the design of gardens. ${ }^{49}$ Since the early I760s Harcourt had been transforming a mount facing his countryseat, Thury-Harcourt (Calvados) into one of the first English-style landscape gardens in France. For Harcourt, such a garden was doubtless a means of expressing his pride in 
THE 'VIEUX CHÂTEAU' OF BETZ

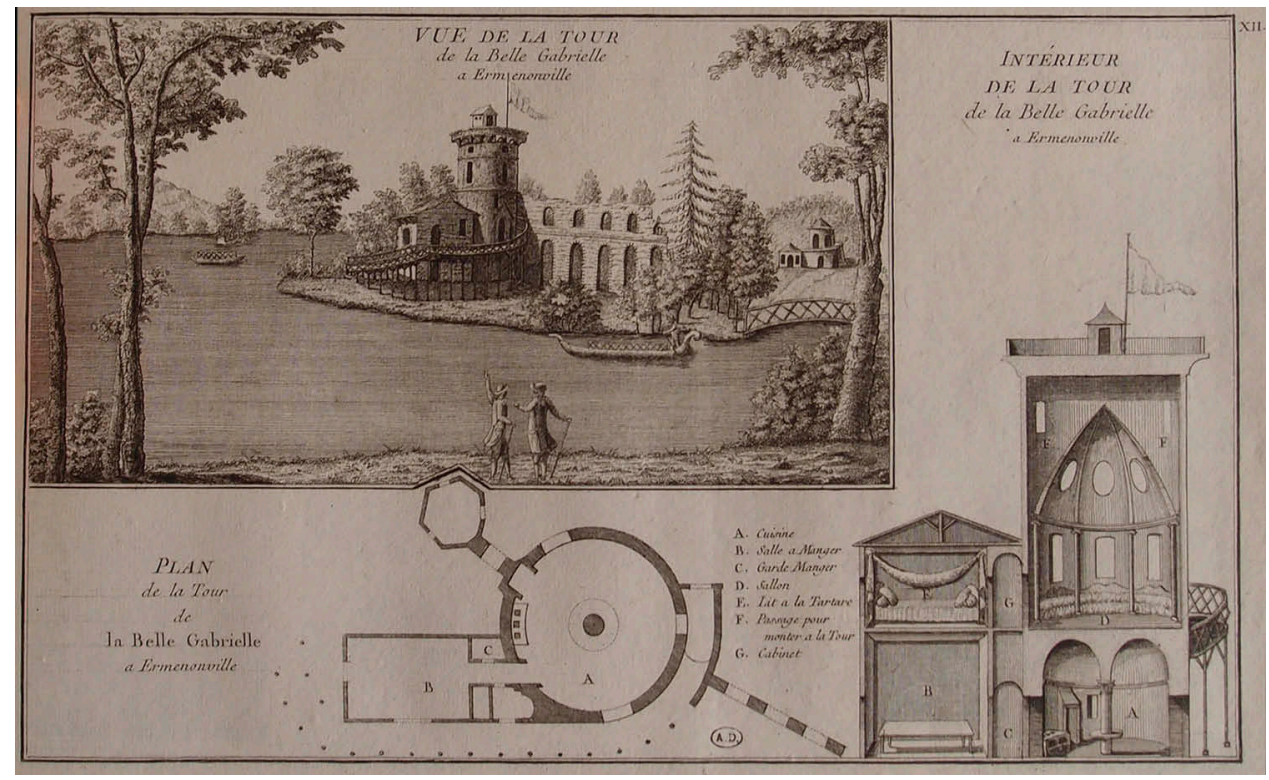

Figure i 2. Georges Louis le Rouge, Detail, Vue de la Tour de La Belle Gabrielle à Ermenonville, engraving, 1784, Cahier XII, plate 13, Bibliothèque des Arts décoratifs, Paris.

the English links of the Harcourt family — his cousin, Simon Harcourt, Ist Earl Harcourt, (I7I4-I777), British ambassador to the French court from I 768 to I772 and an early member of the Society of Dilettanti, had undertaken the remodelling of his country seat of Nuneham Courtenay (Oxfordshire) and the creation of a large landscape garden and model village nearby. It is also probable that Harcourt kept up his ties with the earl's successor, George Simon Harcourt, 2nd Earl Harcourt (I736-I809), an enthusiastic gardenmaker in his own right. ${ }^{50}$ It is perhaps not a coincidence that precisely the same time that Harcourt and Robert were creating the pastiche Vieux château at Betz out of historic architectural elements; the 2nd Earl was reassembling another antiquarian structure, the seventeenth-century Carfax Conduit as an eye-catcher at Nuneham Courtenay.

Since I778, Harcourt and Robert had already been collaborating on Brimborion, the gardens of the marquise de Coislin at Meudon. ${ }^{\text {II }}$ Robert, who already instructed many of his friends and patrons in the arts of drawing and outdoor sketching, made something of a reputation for himself as an artist who could also aid them in the realization of their gardens. A I784 article in the manuscript newsletter Mémoires secrets described how Robert, working in his capacity as dessinateur des jardins $d u$ Roi, aided Louis XVI, who wished to 'oversee and lead the embellishment of his domain himself, in transforming that domain. ${ }^{52}$ While this account was certainly heavily romanticized, it does show how Robert's involvement in a project could be seen as facilitating rather than overshadowing the proprietor in the design of their gardens. Robert also had something of speciality in working with and around medieval structures in garden compositions. In I 777 he laid out the garden of the prince and princesse de Beauvau at Saint-Germain to frame a distant view of the medieval pilgrimage chapel of Saint-Fiacre. ${ }^{53} \mathrm{~A}$ short while year later he worked on behalf of the princesse de Beauvau's brother and sister-in-law, the duc and duchesse de Chabot at La Roche-Guyon incorporating its forbidding medieval keep, the Tour de Guy into a circuit of picturesque 


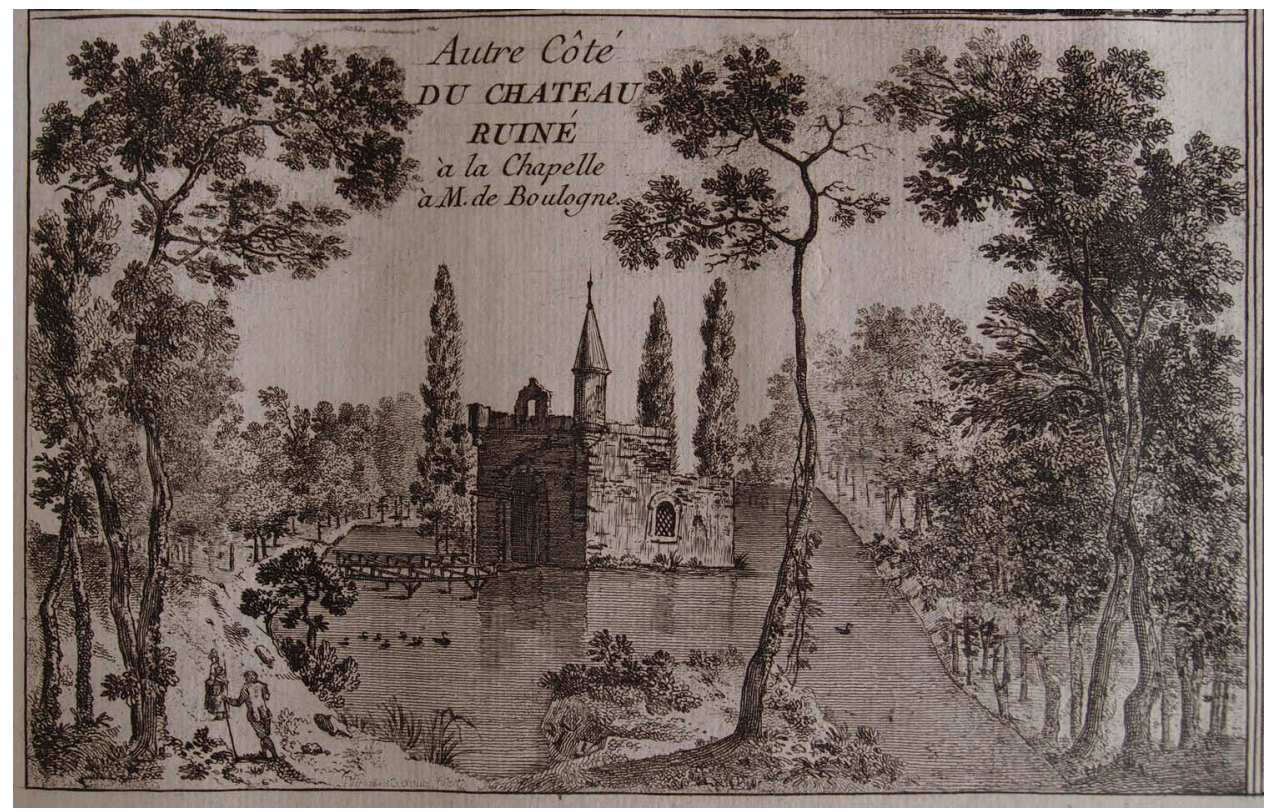

figure I 3. Georges Louis Le Rouge, 'Chateau ruiné à la Chapelle près de Nogent vue de profil par Gentils Architecte', 1784, Cahier XI, plate 10. Bibliothèque des Arts décoratifs, Paris.

promenades. ${ }^{54}$ As Guillaume Faroult observes, Robert also executed a large decor that depicted a gothic fortified tower and semi-ruinous bridge for the salon of Jean Nicolas de Boullongne's château of La Chapelle-Godefroy this painted decor echoed the pastiche gothic ruins in the château's garden that Robert may have also played a part in designing ${ }^{55}$ (figure I3). Like Betz, these gardens also featured at least one historic funerary monument (figure I4). These gardens were visited and described by Condé in a letter to Monaco in Autumn I $788 . .^{56}$

Like many of his contemporaries, Robert was fascinated by the spectacle of the demolition of venerable buildings in Paris in the second half of the I780s - his painted views of the clearing of the houses of the Pont de Notre Dame now in the collections of the Musée Carnavalet and the Church of Les Innocents at the Bowes Museum show (figure I5). As a master of the ruin genre and the architectural caprice and a keen observer of the effects of time on architecture and monuments, it was only natural that such spectacles would lead Robert to reflect on new settings and compositions that would frame and imbue these fragmented vestiges with a new meaning and expressivity. Robert's other professional activities also prepared him for such a task. Since I778, had been tasked by the comte d'Angiviller (I730-I8Io) to reflect on the proper setting for the display of historic artworks from the royal collection in the Grand Galerie of the Louvre just as at the Park of Versailles he was reinstalling the seventeenth-century sculptural groups, les Bains d'Apollon in a picturesque new setting.

The possibility that Robert was working with Brongniart at Betz is especially interesting because he was also probably collaborating with the architect on another very similar garden composition that constituted something of a false historical narrative - the Elysée of Mauperthuis for Anne-Pierre, marquis de Montesquiou-Fézensac (I739-I798). ${ }^{57}$ Like Betz the promenades at the Elysée was conceived as a sequence of pseudo-historical scenes that drew liberally from episodes from Montesquiou-Fézensac's highly romanticized - 


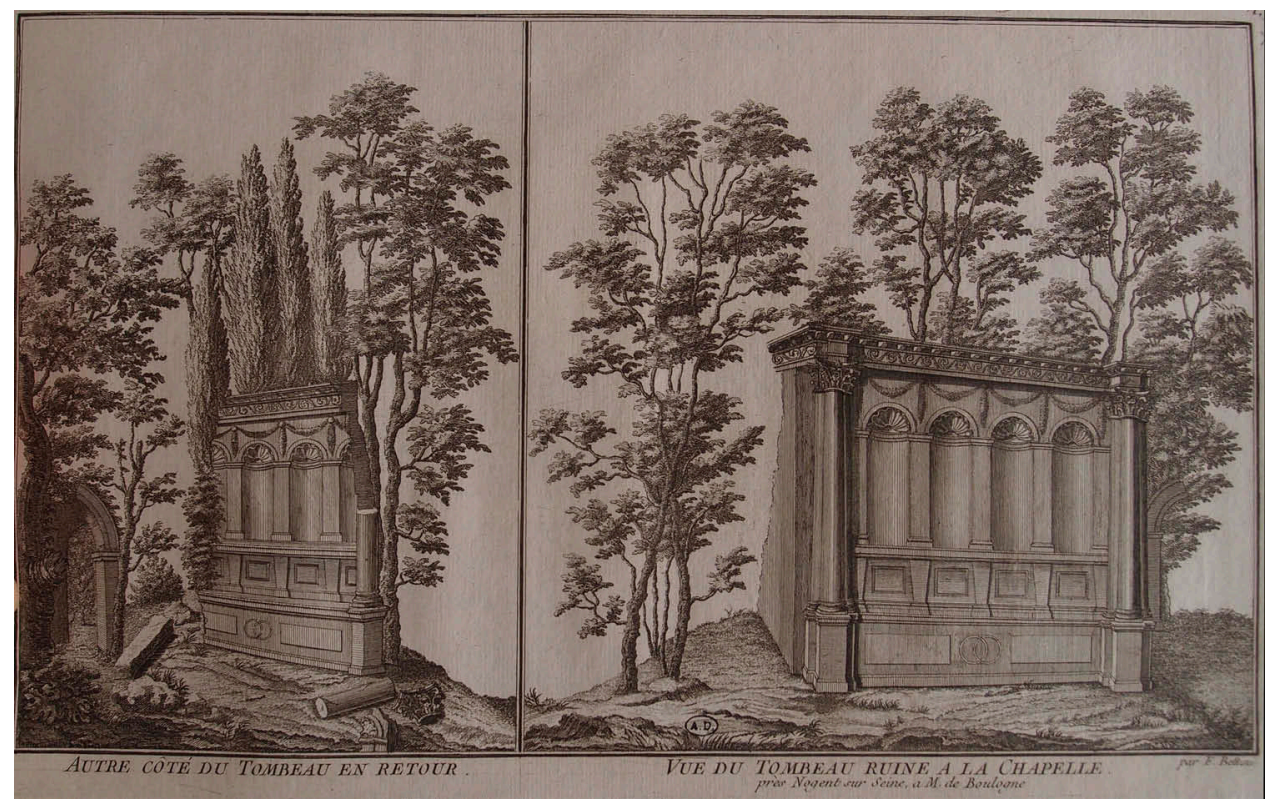

Figu Re I 4. Georges Louis le Rouge, 'Vue du tombeau ruine à la Chapelle prés Nogent sur Seine à M. de Boulogne', 1784, Cahier XI, plate 13. Bibliothèque des Arts décoratifs, Paris.

and widely contested - claims regarding his family history. The garden could be entered through a gothic gatehouse meant to evoke its proprietor's supposed historical links to the musketeer d'Artagnan as well as a Renaissancestyle pavilion that evoked the property's associations with the literary figure the princesse de Clèves. As at Betz, the dénouement of the Elysée of Mauperthuis was a tomb, that of Admiral Gaspard de Coligny (I5 I9-I572), leader of the French Protestants, assassinated on Saint Bartholomew's day. Local legend had that as the Coligny's remains were being conveyed in secret to his château of Chatillon for burial, the party had taken shelter for the night in a cave near the site of the Elysée (figure I6). As at Betz, the immediate setting of Coligny's tomb within Elysée was designed to appear not like a part of the garden but rather as something of a marginal and neglected wilderness. In contemporary depictions Coligny's tomb emerges from dense undergrowth at the edge of the lawn as if it was forgotten and neglected. ${ }^{58}$ This wild setting functioned as a visual cue for the visitor, prompting them to imagine that their discovery of this relic of history was entirely authentic and orchestrated.

Ironically, of course, it was history that finally overtook Betz. Monaco and Condé fled France in the days immediately following the fall of another medieval castle, the Bastille. Monaco died in exile in England in I8I3, 5 years after having finally married Condé. The prince returned to France after the defeat of Napoléon and the re-establishment of the Bourbon monarchy 2 years later. As the estate of an émigrée Betz was confiscated and sold, as was Mauperthuis. The stylistic influence of Betz and Mauperthuis and the other 'historical' gardens of the $178 \mathrm{os}$, however, proved far more enduring. The genre would reach its apogee in the early years of the nineteenth century, when Alexandre Lenoir's (I76I-I839) created a garden extension to his pioneering Musée des Monuments français, called, like Mauperthuis, the Elysée. By Lenoir's own account, it was Coligny's tomb, which Lenoir had salvaged 


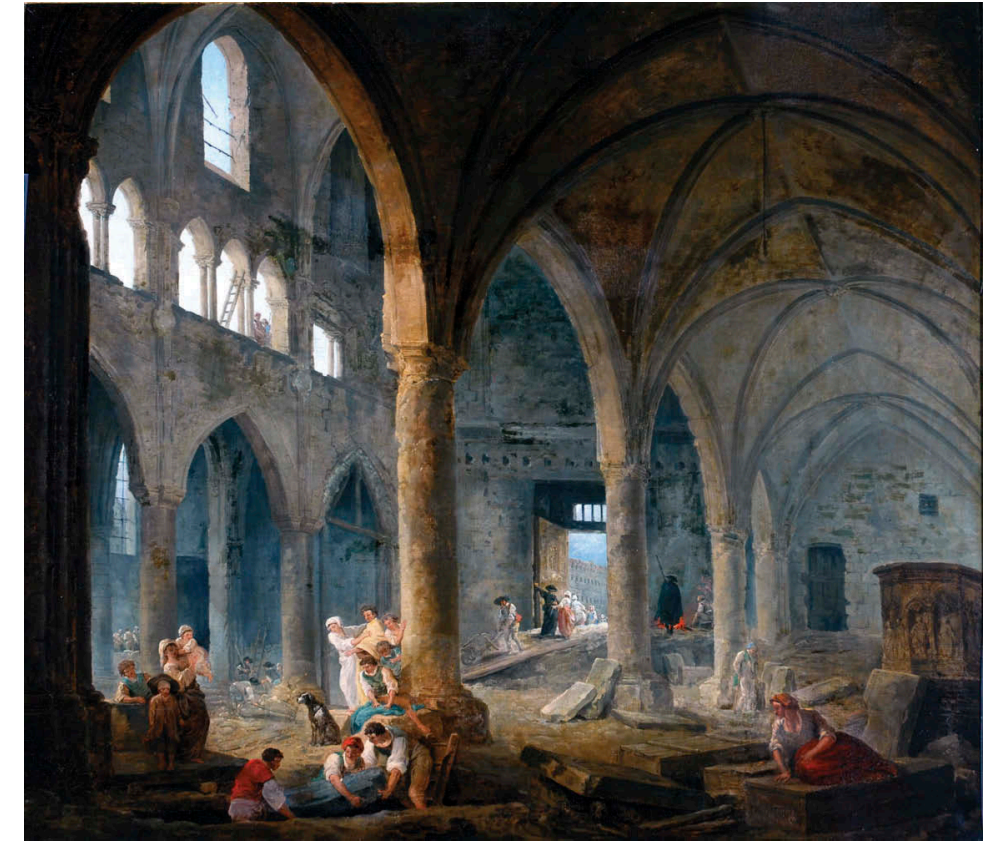

figure i 5. Hubert Robert, The Dismantling of the Church of the Holy Innocents, Paris, France, 1785 C.1785-1787 oil on canvas, 114.6 × 129.5, B.M.312 The Bowes Museum, Barnard Castle, Co. Durham.

from Montesquiou's own garden, that formed the initial genesis of the jardin Elysée des Monuments français. ${ }^{59}$ Much, like Betz and Mauperthuis, Lenoir sought to give his Elysée an unkempt and wholly undesigned appearance, as if these tombs and monuments, which had in fact only just been removed from confiscated churches and châteaux to be brought there, had had centuries to settle in. Here, as at Betz and Mauperthuis, in giving the garden an appearance of wilderness, its designer used rich vegetation to suggest an entirely fictional relationship between these displaced artefacts and their new setting. Hubert Robert evidently appreciated the atmosphere of Lenoir's Elysée as this was a site he frequently came back to in his last years. Robert's friend and collaborator Brongniart also succeed in adapting his vision to the needs of the new regime - in I804, the then first Consul Bonaparte entrusted him with the

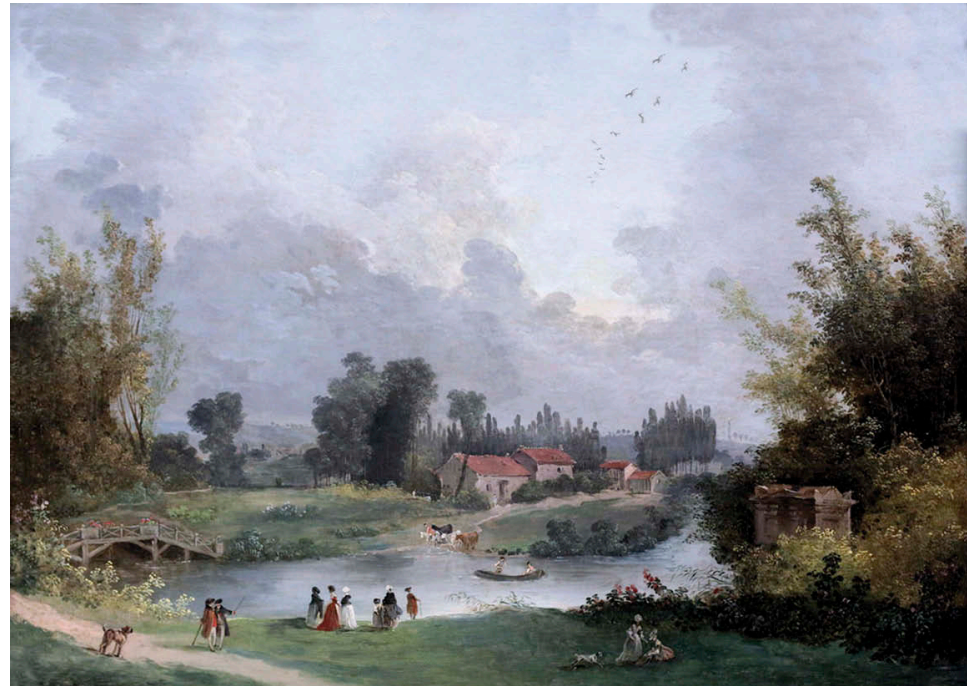

FIGURE I 6. Hubert Robert (1733-1808), Landscape (park) [The tomb of Coligny and Elysée of Mauperthuis], c. 1786, oil on canvas, dimensions H. 40,4; L. 55,2 cm, Germany, Karlsruhe, Staatliche Kunsthalle, Photo (C) BPK, Berlin, Dist RMN-Grand Palais / Annette Fischer/ Heike Kohler.

design of what was to become the Cemetery of Père-Lachaise. The plans and perspectives he produced show the debt that this first garden cemetery owes to the aristocratic gardens of the last years of the Ancien Regime. While Monaco and Montesquiou sought to use their gardens to communicate their own personal narratives to the public, the Elysée and Père-Lachaise aided the new regime in defining a collective French sense of history and identity.

\section{Disclosure statement}

No potential conflict of interest was reported by the author.

Adjunct lecturer, Art \& Design History, Parsons / The New School, Paris, France

Doctoral candidate, Department of History, Queen Mary - University of London, London, UK 


\section{NOTES}

I. On the sources of the medieval revival in eighteenth-century France, see René Lanson, le Goût $d u$ moyen age en France au XVIIIe siècle (Paris: G. Vanoest, I928); also Le Gothique retrouvé avant Viollet-leDuc, exhibition catalogue (Paris: Caisse nationale des monuments historiques et des sites, I979).

2. On the life of the princesse de Monaco, see Pierre de Ségur, 'Marie-Catherine de Brignole, princesse de Monaco, I736-I8I3', Revue des deux mondes, 4ème période, tome I 50, I 898 , pp. 583-628. On her relations with the prince of Monaco, see Thomas Fouilleron, Des Princes en Europe: les Grimaldi de Monaco, des Lumières au printemps des peuples (Paris: Honoré Champion, 2012).

3. A verse description of the garden was authored by one of the participants in its conception, JosephAntoine-Joachim Cerutti, Les Jardins de Betz, poème, accompagné de notes instructives sur les travaux champêtres (Paris: Chez Desenne, I792); An anonymous account of the garden from the I79os, perhaps by the guidebook writer Mérigot, was discovered and republished with extensive notes by Gustave Macon as Les Jardins de Betz (Senlis: impr de E. Dufresne, I908); a I788 account by Bertrand Barère was recently brought to light by Maité Bouyssy and annotated and published as Maité Bouyssy, 'Un philosophe moral dans le parc de Betz: la promenade de Bertrand Barère en I788', Polia: revue de l'art des jardins, 6, Autumn, 2006, pp. 89-130; Bouyssy's article is preceded by an excellen summary of the history of the garden and its historiography, Nicole Gouiric, 'Betz: préambule', Polia, 6, Autumn, 2006, pp. $83-88$; the garden is also described in Alexandre de Laborde, Description des nouveaux jardins de la France et de ses anciens châteaux (Paris: Delance, I808), pp. I69-I74.

4. These documents are now largely divided between the Archives du Palais princier de Monaco (APM), the Archives du musée Condé de Chantilly, the
Archives départmentales de l'Oise (ADO), and the Archives nationales in Paris (AN). My thanks to Thomas Fouilleron and Thomas Blanchy at the Archives du Palais princier de Monaco for facilitating my research there.

5. Three views of the château, the ruined tower and the Temple of Love and Friendship by Constant Bourgeois (I 767-I 84I) appeared alongside Laborde's account. Five rather crude views of the ruin, Chinese pavilion, chapel, hermitage, mill and Temple of Repose were also published by a certain Chéreau at the end of the eighteenth century. A far more rare engraving by the artist Thomas Charles Naudet (I773-I8Io) of the side elevation of the ruined tower was published in Jacques Cambry's Description du département de l'Oise (Paris: Didot l'ainé, I 803).

6. Macon, Betz, p. 200 \& note II, p. 232.

7. See ibid., pp. 197-200.

8. See Gustave Macon, Les Arts dans la maison de Condé (Paris: Librairie de l'art ancien et modern, I903), pp. I3O-I3I.

9. Barthélemy's reply to the princesse's query survives, $\mathrm{ADO} / \mathrm{JPi} 36 / 70$ / 2. Widely recognized as the authority on classical archaeology in France, Barthélemy was also consulted on the selection of antique sculptures for the financier Simon-Charles Boutin's garden on the outskirts of Paris. See Aubin-Louis Millin, Monuments antiques inédits ou nouvellement expliqués (Paris: Didot Jeune, I802), T.I, p. I05. Barthélemy was also the secretary of the duc de Choiseul-Stainville, whose niece Françoise MarieThérèse de Choiseul-Stainville (I767-I794), had married the princesse de Monaco's younger son. Joseph Marie Jérôme Honoré Grimaldi (I763-I8I6). The marriage took place on the 6 April 1782 , thus shortly before the construction of the Temple.

Io. See Pierre Laujon, Matroco, drame burlesque, en quatre actes, et en vers mêlé d'ariettes et de vaudevilles; représenté devant Leurs Majestés, à Fontainebleau, en 1777 (Paris: P. Robert-Christophe Ballard, I778). The work's history and links with Condé is described in Pidansat de Mairobert, Mémoires secrets pour servir á l'histoire de la République des lettres en France, depuis 1762 jusqu'a nos jours (Tome X) (London: John Adamson, I780), pp. $297-298$

I I. See Bouyssy, 'Un philosophe moral', p. Io9.

2. Macon, Betz, p. I90.

I3. See ibid., note 6, p. 42 .

I4. The I788 description of Ermenonville also emphasizes the views of authentic medieval structures that could be had from that garden's pastiche gothic tower. See [Girardin de Stanislas], Promenade ou Itinéraire des jardins d'Ermenonville, auquel on a joint vingtcinq de leurs principales vues, dessinées E gravées par Mérigot fils (Paris: chez Mérigot père, I788), p. 63.

I 5. 'D.M. [diis manibus], Illoc memorum alta quies loca longum attestentur luctum, silentia sacra, procul este profani.' The original text is cited in Macon, Betz, p. I9I; as Nicole Gouiric observes, the Lombardy poplar was a mainstay of modern gardens in the I 780 os and the cultivar was especially prized for its associations with Ermenonville and the island-grave of Rousseau. See Nicole Gouiric, 'La Peuplomanie dans les jardins de la seconde moitié du XVIIIème siècle en France: propos inspiré par les peupliers de Méréville', Polia, no. Io, 2008, pp. 33-64.

6. On the Saints-Innocents, see Madeleine Foisil, 'Les Attitudes devant la mort au XVIIIe siècle: sépultures et suppressions de sépultures dans le cimetière parisien des Saints-Innocents', Revue Historique, no. 25I, Avril-Juin, I974, pp. 303-330.

7. On Quatremère de Quincy and the fountain, see David Gilks, 'The Fountain of Les Innocents and its place in the Paris cityscape, I549-I788', Urban History, forthcoming.

I8. Pajou's work on the memorials and monuments at Betz coincides his contemporaneous collaboration 
with Robert on structures for the park of Méréville. On Pajou's work at Méréville, see Olivier Choppin de Janvry, 'Méréville', L'Oeil, i 80, December, I969, pp. 30-4I, 83, 96

I9. Macon, Betz, p. I92.

20. Macon, Les Arts, p. II6.

21. Macon, Betz, p. 192.

22. Ibid., p. I92.

23. Ibid., p. I94

24. Ibid., Note 9, p. 226

25. Macon provides a copy of the hermit's contract, see ibid., pp. 260-2 I6.

26. Luc-Vincent Thiéry, Guide des amateurs et des étrangers voyageurs: ou Description raisonnée de cette ville, de sa banlieue, et de tout ce qu'elles contiennent de remarquable, vol. II (Paris: Hardouin et Gattey, I787), pp. $605-606$

27. Macon, Betz, p. I94.

28. See 'Matroco' in César.org (Calendrier électronique des spectacles sous l'ancien régime et sous la révolution).

29. See ADO / JPi36 / 7i / I, Letter $N^{\circ}$ 9: Letter from the prince de Condé to Mme de Monaco.

30. See ADO / JPז36 / 2 / i: 'Notes pour le vieux château de Betz'

3I. Bouyssy, 'Un philosophe moral', p. I02.

32. 'Le Raphaël des paysages,/ Le poète du temps, Robert a crayonné / Ce château pittoresque en naissant ruiné. / L'artiste en les formant mutila ses ouvrages: / Les longs siècles pour eux furent des courts instans. / Chaque coup de marteau leu imprima cent ans. / Pour consoler, flatter leur précoce vieillesse, / Il leur donna l'orgueil de l'antique noblesse...' Joseph-Antoine-Joachim Cérutti, Les Jardins de Betz, poème (Paris: Chez Desenne, I792), pp. $44-45$.

33. The scandalous nature of Condé and Monaco's relationship, and Louis XVI and Marie-Antoinette's disapprobation of it was the subject of a number of articles in the contemporary press. See especially, de Mairobert, Mémoires secrets, T.27: 264 (23 July I783) and T.27: 279 (I I August 1784). This renewed and noticeably hostile wave of coverage of the couple's liaison may be linked to the marriage of the princesse's son to the niece of the duc de ChoiseulStainville (see note 9).

34. On Brongniart and the hôtel de Monaco, see Monique Mosser and Béatrice de Rochebouët, AlexandreThéodore Brongniart 1739-1813: architecture et décor, ex. cat. (Paris: Les Musées de la Ville de Paris, I986), pp. $54-64$.

35. Frénilly's own château, Bourneville, was located only $15 \mathrm{~km}$ from Betz in Marolles. See FrançoisAuguste Fauveau de Frénilly, Souvenirs du baron de Frénilly, pair de France, (1768-1828) (Paris: Plon, I909), p. 292.

36. Nanteuil-le-Haudouin and Crépy-en-Valois were both given extensive descriptions and illustrations in Jean-Benjamin de Laborde's Description générale et particulière de la France... [Voyage pittoresque de la France, avec la description des toutes ses provinces...]. Io vols. (Paris: Imprimerie de Pierres, Lamy, I78 I-I 800).

37. See Promenade ou Itinéraire des jardins d'Ermenonville, pp. $6 \mathrm{I}-65$

38. Bouyssy, 'Un philosophe moral', p. IO2. The hôtel was confiscated from the princesse along with the rest of the domain.

39. On Barré, see Michel Gallet, Les Architectes parisiens du XVIIIème siècle: dictionnaire biographique et critique (Paris: Mengès, I995), p. 39.

40. See APM / H 90, Sept I78

4I. See APM / H 96, Article I59, I3 May I788 and APM / H 96, Article I84 \& I89, 7 \& 24th June I 788 .

42. Ganay cites a letter from the Harcourt family archives at the château of Thury-Harcourt (since destroyed) dated 26 July I78I, in which Condé recounts to Harcourt that his description of the duc's gardens at Thury-Harcourt had greatly interested Monaco and that he hoped that he would soon be called to Betz. See Ernest de Ganay, 'Les Jardins à l'anglaise en France au dix-huitième siècle', (University of Paris, I923), T.I, p. 340.

43. This letter was transcribed by Pierre de Ségur, along with a number of others, which are conserved in the
Departmental Archives of Oise, Beauvais. Ségur's extracts are reproduced in Macon, Betz, pp. 79-83.

44. The accounts and receipts of the princesse's persona expenses from the years I780 to I788, which includes much of the outlays for Betz, are conserved at the Palace Archives, Monaco. See APM H87Ho6.

45. On these men, see Macon, Les Arts, p. i i6.

46. See 'Projet d'un oratoire à placer au fond du parc de l'hôtel de Monaco, rue Saint-Dominique', Louvre, Cabinet des dessins, Fonds Brongniart; the structure is illustrated in Mosser, Brongniart, p. 276.

47. APM / H 96 / Art. I24: Quittance de l'architecte Brongniart, I 5 th April I 788 .

48. In particular, see the tower at Betz bears a remarkable resemblance to the drawing now titled 'Projet de "châtelet" néo-gothique pour la porterie d'un domaine', RF 50 607-50610, Louvre, Cabinet des dessins, Fonds Brongniart.

49. Harcourt's manuscript, was rediscovered by Ernest de Ganay and published in I9I9 as François-Henri d'Harcourt, Traité de la décoration des dehors, des jardins et des parcs (Paris: Emile-Paul, I9I9).

50. On the landscape projects of the 2nd Earl Harcourt, see Mark Laird and John Harvey, “'Our Equally Favorite Hobby Horse": The Flower Gardens of Lady Elizabeth Lee at Hartwell and the 2nd Earl Harcourt at Nuneham Courtenay', Garden History I $8 / 2$, I990.

5I. Ernest Ganay cites two letters from Coislin to Harcourt from the Harcourt Archive, dated 26 November 1779 and I 3 June 1783 that reference Harcourt and Robert's simultaneous involvement on the design of the garden of Brimborion. Both letters were destroyed with the entirety of the archive in I944. See Ganay, 'Les Jardins à l'anglaise', p. I 8 I-I 82 .

52. "Le Roi... s'occupe des améliorations \& d'embellissements de ce château, il suit \& dirige lui-même le travail... J'ai vu le plan dressé \& levé par Sa Majesté très-promptement; elle l'a confié pour exécution à M. Robert, 'le peintre, qui vient d'être nommé dessinateur des jardins du roi,'Mémoires secrets, 27 November 1784 , T. 27 , p. 38 


\section{THE 'VIEUX CHÂTEAU' OF BETZ}

53. For Blaikie's description of this project, see Thomas Blaikie, in Francis Birrell (ed.), Diary of a Scotch Gardener at the French Court at the End of the Eighteenth Century (London: Routledge \& Sons, I93 I), p.I59.

54. See Gabriel Wick, 'Hubert Robert and the Renovation of the Tour de Guy at the château of La Roche-Guyon,' Garden History, 4I/2, 20I3, pp. 224-243.

55. See Guillaume Faroult and Catherine Voiriot (eds.) Hubert Robert 1733-1808: un peintre visionnaire, ex. cat. (Paris: Somogy, Editions du Louvre, 20I6), pp. 268-27I.
56. The letter is conserved at the Archives départementales de l'Oise. See Archives départementales de l'Oise, Ji38 / io.

57. On the Elysée, see Mosser and Rochebouët, Brongniart, pp. 262-268; also Jean-Paul Denef, Mauperthuis: un parc au siècle des lumières (Dax: G. Barrouillet, I992); also Robin Middleton, 'The Château and Gardens of Mauperthuis: The Formal and the Informal' in John Dixon Hunt (ed.), Garden History: Issues, Approaches, Methods (Washington, DC: Dumbarton Oaks Research Library and Collection, 1992). Also see Christophe Morin, 'Le Château et la parc de
Mauperthuis: programme utopique et fabriques d'Histoire', shortly to be published by the Groupement archéologique de Seine-et-Marne, Nemours, France.

58. This mise-en-scène is particularly evident in a depiction by Robert of the tomb and its setting, now at the Staatliche Kunsthalle in Karlsruhe (Hubert Robert, 'Park Landscape', I786, oil on canvas, H. I 7.5; L.23.8, Inv. $\mathrm{N}^{\circ} 2665$ )

59. The history of Coligny's remains is recounted in Lenoir, Histoire des arts en France, prouvée par les monuments (Chez l'auteur au musée, i 8 I I) note I, p. 359 